\title{
Co-composting of empty fruit bunches and partially treated palm oil mill effluents in pilot scale
}

\begin{abstract}
The main objective of this study is to investigate the physicochemical changes of the cocomposting Empty Fruit Bunch (EFB) with partially treated palm oil mill effluent (POME) in pilot scale. The partially treated POME from anaerobic pond was sprayed onto the shredded EFB throughout the treatment. The composting materials were turned over one to three times per week for aeration. Temperature and oxygen were monitored at different depths of the composting piles. Parameters such as $\mathrm{C}, \mathrm{N}, \mathrm{pH}$, nutrients, heavy metals and total bacteria count were also determined. The temperature was increased up to $58.5 \hat{\mathrm{A}}^{\circ} \mathrm{C}$ at day three of treatment, after that fluctuated between 50 to $62 \hat{\mathrm{A}}^{\circ} \mathrm{C}$ and then decreased in the latter stage of the process. The $\mathrm{pH}$ of the system $(7.75-8.10)$ did not vary significantly during the treatment period while moisture content was reduced from $65-75 \%$ to about $60 \%$ at the end of the treatment. The initial $\mathrm{C} / \mathrm{N}$ ratio of 45 was significantly reduced to 12 after 60 days of composting. The final cured compost contained a considerable amount of nutrients (carbon, nitrogen, phosphorus, potassium, calcium, magnesium, sulfur and iron) and trace amounts of manganese, zinc, copper. In addition, very low levels of heavy metals were detected in the compost. The number of bacteria involved in the composting process was decreased at the end of the composting period. The results obtained indicated that pilot scale of co-composting EFB with partially treated POME gave acceptable quality of compost and ease in operation. The compost product may useful in palm oil plantation as fertilizer and soil amendment.
\end{abstract}

Keyword: Empty fruit bunch; Partially treated palm oil mill effluent; Composting 